\section{EDUCATION}

Research, Innovation and Solutions on-line ${ }^{(2)}$

\section{Electronic Journal of Research}

in Educational Psychology

PSYCHOLOGY

I+D+i

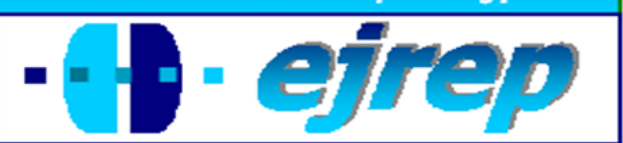

Editorial EOS

\title{
Career decision self-efficacy among Turkish undergraduate students
}

\author{
Erkan Işık
}

Department of Psychological Counseling \& Guidance,

Mevlana University

\section{Turkey}

An earlier version of this research was presented at the International Conference of Psychology and Education in Portugal, March 2009. We would like to thank to Editor Juan L. Benítez and two anonymous reviewers for their helpful comments and suggestions. Correspondence concerning this article should be addressed to Erkan Işık, Department of Psychological Counseling and Guidance, Mevlana University, Turkey.

e-mail; erkanthelight@yahoo.com

(C) Education \& Psychology I+D+i and Editorial EOS (Spain) 


\begin{abstract}
Introduction. The aim of this study was to investigate the career decision-making selfefficacy in a sample of 356 Turkish undergraduate students.
\end{abstract}

Method. With this purpose, 356 (138 females; 218 males) Turkish undergraduate students aged 17-24 completed a Turkish-translated version of Career Decision Self-Efficacy ScaleShort Form (CDSE-SF) to evaluate their career decision self-efficacy. Means and standard deviations were given to examine perceived difficulty of career decision-making tasks arranged from most to least difficult. T-test analyses were conducted to test for age, gender, and major differences on career decision self-efficacy scores.

Results. Results demonstrated that the most difficult tasks were on problem solving subscales and the least difficult tasks were on self-appraisal and occupational information subscales. According to the results of t-tests, the older group (21 and over) scored significantly higher on goal selection, planning, self-appraisal, and occupational information subscales than younger group (20 and below). No gender differences were found in any subscales of career decision self-efficacy scale. According to major, students from engineering departments (Mechanical, Chemical, Geological, Environmental, Electrical \& Electronic, Geodesy \& Photogrammetry) scored significantly higher on goal selection, self-appraisal, and occupational information subscales than the students from social departments (Economy, Management, International Relations).

Discussion and conclusions. The results suggested that career-decision self-efficacy scores of Turkish undergraduate students are similar to the previous research conducted mostly in English-speaking countries. These findings can be a support for the use of CDSES-SF with Turkish undergraduates and a support of its use in other non-English-speaking countries. Future research is encouraged to further explore such task difficulty, gender, age, and major differences using CDSES-SF with various populations in other non-English-speaking countries.

Keywords: career decision, self-efficacy, Turkish undergraduate students, CDSE-SF

Received: 03/04/10 Initial Acceptance: 03/08/10 Definitive Acceptance: 04/09/10 


\section{Autoeficacia en la decisión de carrera en estudiantes turcos de grado \\ Resumen}

Introducción. El objetivo del estudio fue investigar la autoeficacia en la elección de la carrera en una muestra de 356 estudiantes turcos de grado.

Método. Con este objetivo, 356 (138 chicas; 218 chicos) estudiantes de grado entre los 17 y los 24 años completaros la versión turca del Career Decision Self-Efficacy Scale-Short Form (CDSE-SF) para evaluar su autoeficacia en la elección de la carrera. Las medias y las desviaciones estándar se utilizaron para valorar la dificultad de las tareas en la decisión de mayor a menor dificultad. El análisis de la $t$ se realiza para valorar las puntuaciones por edad, sexo, y valoar las diferencias en autoeficacia.

Resultados. Los resultados muestran que la tareas más difíciles fueron las subescalas de solución de problemas y las más fáciles las relacionadas con las subescalas de autoevaluación e información ocupacional. De acuerdo con los resultados de la prueba $t$, el grupo de alumnos con más edad (21 años o más) punturaron significativamente mejor en los objetivos de selección, planificación, autoevaluación e información ocupacones que el alumnado más joven (20 años o menos). No se encuentran diferencias en función del sexo en ninguna de las subescalas. De acuerdo con el alumnado, los estudiantes de departamentos de ingeniería (Mecánica, Química, Geología, Medio Ambiente, Electriciad y Electrónica, Geodeis y Fotometría) puntuaron significativamente más alto en selección de objetivos, autoevaluación e información ocupaciones que el alumnado de departamentos de sociales (Economía, Gestión, Relaciones Internacionales).

Discusión y Conclusión. Los resultados sugierine que las puntuaciones en autoeficacia de elección de la carrera entre el alumnado turco es similar a otros estudios realizados en países de habla inglesa. Estos hallazgos puede apoyar el uso de CDSES-SF entre el alumnado turco. Futuras investigaciones deberán explorar la dificultad de la tarea, el sexo y la edad utilizando el CDSES-SF en poblaciones no anglosajonas.

Palabras Clave: elección de la carrera, autoeficacia, estudiantes de grado, CDSE-SF

Recibido: 04/03/10 Aceptación Inicial: 08/03/10 Aceptación Definitiva: 09/04/10 


\section{Introduction}

Self-efficacy has been defined as the "beliefs in one's capabilities to organize and execute the courses of action required to produce given attainments"' (Bandura, 1997, p.3). According to Bandura (1977), individuals' confidence and beliefs in their ability determine how much effort they will expend and how long they will persist even if they encounter obstacles or aversive experiences. Therefore, these confidence and beliefs influence their choices, performance, and persistence in these tasks and behaviors. Similarly, taking its roots from general social cognitive theory of Bandura (1977), Social Cognitive Career Theory posits that self-efficacy expectations both directly and indirectly (over outcome expectations) predict individuals' interests, goals, choices, and performances on specific domains (Bethencourt \& Cabrera, 2006; Lent, Brown, \& Hackett, 1994, 2002). Thus, individuals who have more selfefficacy on a specific domain will develop more interest, persist even if they encounter obstacles or aversive situations and probably attain more successful performance accomplishments on this specific domain. It can be concluded from these statements that efficacy beliefs are significant predictors of our thought and action in general. The term self-efficacy then helps us to understand why two individuals with similar abilities can not achieve the same performances in many instances (Bandura, 1986).

Since self-efficacy is not considered as a global trait, but rather as a dynamic set of beliefs that are linked to particular performance domains (Lent, 2005), it is used with various domains such as mathematics self-efficacy (Betz \& Hackett, 1983; Lopez, Lent, Brown, \& Gore, 1997), computer self-efficacy (Cassidy \& Eachus, 2002), internet self-efficacy (Eastin \& LaRose, 2000), and career decision self-efficacy (Taylor \& Betz, 1983; Taylor \& Popma, 1990). From these specific constructs, career decision self-efficacy has probably received the most research attention over the last three decades.

In the context of career decision self-efficacy, there has been many attempts to conduct researches on the construct in many different countries and cultures (Creed, Patton \& Watson, 2002; Hampton, 2005; Martínez, 2007; Mau, 2000; Patel, Salahuddin \& O’Brien, 2008) since the development of Career Decision-Making Self-Efficacy Scale by Taylor and Betz (1983). Career decision self-efficacy is conceived as individuals' beliefs about their competency in career related tasks (Betz \& Hackett, 1981). These tasks, as cited by Crites 
(1976), include: (a) accurate self-appraisal, (b) gathering occupational information, (c) goal selection, (d) making plans for the future, and (e) problem solving. Thus, high career decision self-efficacy refers to the high efficacy in these tasks. Taylor and Betz (1983) used these five competencies as the sub-scales of Career Decision Self-Efficacy Scale.

Previous research demonstrated that higher career decision self-efficacy is associated with higher career exploration behavior and vocational identity (Blustein, 1989; Gushue, Clarke, Pantzer \& Scanlan, 2006), career maturity (Patton \& Creed, 2001), career commitment (Chung, 2002) and less career indecision (Taylor \& Betz, 1983). Furthermore, individuals with higher career decision self-efficacy were better in career planning and goal setting when they are compared with their counterparts (Rogers, Creed, \& Glendon, 2008).

When compared with other constructs within career behavior, career decision selfefficacy has received more research attention due to its important role in career decisionmaking and career interventions (Betz, Hammond \& Multon, 2005). According to Betz \& Voyten (1997), application of self-efficacy theory to the study of vocational behavior has been one of the most heuristic and useful practices in career development research. Both its practical applications to career interventions and significance in predicting many career constructs such as career exploration behavior, vocational identity, career maturity, career commitment, career indecision make the term career decision self-efficacy very useful and popular in career research. However, there is still less information on career decision self-efficacy literature for different cultures, especially in non-English-speaking countries. Therefore, the aim of this study was to investigate the career decision-making self-efficacy in a sample of Turkish undergraduate students.

\section{Method}

\section{Participants}

Participants were 356 freshmen (61\% male, 39\% female) from engineering (53\%) and social departments (47\%) of a large state university in Turkey. Ages ranged from 17 to 24 years with a mean of 19.57 years $(S D=1.23)$. The gender distribution and the average age of the sample were similar to the gender distribution and the average age of all freshmen at the university. 


\section{Instruments}

Career Decision Self-Efficacy Scale-Short Form (CDSES-SF). The CDSESSF (Betz, Klein, \& Taylor, 1996) is a 25-item scale that was used to assess participants' confidence in their ability to successfully complete five tasks necessary to making career decisions: engaging in accurate self-appraisal, gathering occupational information, engaging in goal selection, planning for the future, and engaging in problem solving. Participants responded to each item using a 5 -point Likert scale $(1=$ no confidence at all; $5=$ complete confidence $)$. Scores for the five subscales were created by summing responses to the five items comprising each, resulting in a possible range from 5 to 25 for each subscale, with higher numbers reflecting higher self-efficacy. Betz et al. (1996) reported an internal reliability coefficient of .94 for the total scale and coefficients ranging from .73 (self-appraisal) to .83 (goal selection) for the subscales. For this study, a Turkish version of the CDSES-SF was used. The internal reliability coefficient was .88 for the total scale, a seven week test-re-test reliability coefficient was .81 , and item total correlations ranged between .34-.62.

Demographic questionnaire. A one-page demographic questionnaire was used to collect information on participants' age, gender, and major.

\section{Procedure}

Instruments containing the CDSE-SF and asking questions about age, major, and gender were distributed throughout the day by the researcher to participants in the classrooms of professors who had agreed to participate. Students were asked to complete the instruments during class time and were informed that their participation was voluntary and that their responses would be kept anonymous.

\section{Results}

Perceived Difficulty of Career Decision-Making Tasks

The means and standard deviations of scores obtained for each of the 25 items are shown in Table 1. As seen in the table, perceived difficulty of tasks ranged from 3.00 (repre- 
senting "some confidence" in one's ability to perform the task) to 4.18 (representing "considerable confidence" in one's ability to perform the task). The most difficult item was "Change majors if you did not like your first choice," and the least difficult was "Decide what you value most in an occupation." The 5 most difficult items included four problem solving and one occupational information subscale. The 5 least difficult items included two self-appraisal, two occupational information and one goal selection subscale.

Table 1. Perceived Difficulty of Career Decision-Making Tasks Arranged from Most to Least Difficult

\begin{tabular}{|c|c|c|c|c|}
\hline \multirow[b]{2}{*}{ Item } & \multicolumn{2}{|c|}{$\begin{array}{l}\text { Confidence } \\
\text { rating }\end{array}$} & \multirow{2}{*}{$\begin{array}{c}\text { Order } \\
\text { Of } \\
\text { Difficulty }\end{array}$} & \multirow{2}{*}{ Subscale } \\
\hline & $M$ & $S D$ & & \\
\hline Change majors if you did not like your first choice & 3.00 & 1.30 & 1 & problem solving \\
\hline $\begin{array}{l}\text { Change occupations if you are not satisfied with the one } \\
\text { you enter }\end{array}$ & 3.49 & 1.09 & 2 & problem solving \\
\hline $\begin{array}{l}\text { Identify some major or career alternatives if you are } \\
\text { unable to get your first choice }\end{array}$ & 3.49 & 1.06 & 3 & problem solving \\
\hline Find information about graduate or professional schools & 3.53 & 1.10 & 4 & $\begin{array}{l}\text { occupational infor- } \\
\text { mation }\end{array}$ \\
\hline $\begin{array}{l}\text { Determine steps to take if you're having academic trou- } \\
\text { ble with your major }\end{array}$ & 3.61 & 0.85 & 5 & problem solving \\
\hline $\begin{array}{l}\text { Make a career decision and then not worry if it was } \\
\text { right or wrong }\end{array}$ & 3.63 & 1.01 & 6 & goal selection \\
\hline $\begin{array}{l}\text { Figure out what you are and are not ready to sacrifice } \\
\text { for your career goals }\end{array}$ & 3.67 & 1.04 & 7 & self-appraisal \\
\hline $\begin{array}{l}\text { Find out employment trends for an occupation over the } \\
\text { next } 10 \text { years }\end{array}$ & 3.68 & 1.00 & 8 & $\begin{array}{l}\text { occupational infor- } \\
\text { mation }\end{array}$ \\
\hline Prepare a good resume & 3.77 & 0.96 & 9 & planning \\
\hline Successfully manage the job interview process & 3.80 & 0.97 & 10 & planning \\
\hline Make a plan of your goals for the next 5 years & 3.81 & 0.88 & 11 & planning \\
\hline Accurately assess your abilities & 3.91 & 0.89 & 12 & self-appraisal \\
\hline $\begin{array}{l}\text { Determine the steps you need to successfully complete } \\
\text { your chosen major }\end{array}$ & 3.92 & 0.75 & 13 & planning \\
\hline Identify employers relevant to your career possibilities & 3.96 & 0.83 & 14 & Planning \\
\hline $\begin{array}{l}\text { Persistently work at your major or career goal even } \\
\text { when you get frustrated }\end{array}$ & 3.98 & 0.95 & 15 & problem solving \\
\hline Choose a major or career that will fit your interests & 4.02 & 0.85 & 16 & goal selection \\
\hline $\begin{array}{l}\text { Select one occupation from a list of potential occupa- } \\
\text { tions you are considering }\end{array}$ & 4.03 & 0.79 & 17 & goal selection \\
\hline $\begin{array}{l}\text { Find the average yearly earnings of people in an occu- } \\
\text { pation }\end{array}$ & 4.03 & 0.87 & 18 & $\begin{array}{l}\text { occupational infor- } \\
\text { mation }\end{array}$ \\
\hline Determine what your ideal job would be & 4.07 & 0.92 & 19 & self-appraisal \\
\hline Choose a career that will fit your preferred lifestyle & 4.08 & 0.89 & 20 & goal selection \\
\hline
\end{tabular}


Table 1 Continued

\begin{tabular}{|c|c|c|c|c|}
\hline \multirow[b]{2}{*}{ Item } & \multicolumn{2}{|c|}{$\begin{array}{l}\text { Confidence } \\
\text { rating }\end{array}$} & \multirow{2}{*}{$\begin{array}{c}\text { Order } \\
\text { Of } \\
\text { Difficulty }\end{array}$} & \multirow{2}{*}{ Subscale } \\
\hline & $M$ & $S D$ & & \\
\hline Select one major from a list you are considering & 4.08 & 0.77 & 21 & goal selection \\
\hline Determine the kind of lifestyle you would like to live & 4.15 & 0.82 & 22 & self-appraisal \\
\hline $\begin{array}{l}\text { Use the Internet to find information about occupations } \\
\text { that interest you }\end{array}$ & 4.16 & 0.99 & 23 & $\begin{array}{l}\text { occupational infor- } \\
\text { mation }\end{array}$ \\
\hline $\begin{array}{l}\text { Talk with a person already employed in a field you are } \\
\text { interested in }\end{array}$ & 4.17 & 0.95 & 24 & $\begin{array}{l}\text { occupational infor- } \\
\text { mation }\end{array}$ \\
\hline Decide what you value most in an occupation & 4.18 & 0.79 & 25 & self-appraisal \\
\hline
\end{tabular}

\section{Gender Differences}

Results of independent sample t-test for gender differences showed no significant gender differences between male and female students on the subscales of CDSE-SF.

\section{Age Differences}

Results of independent sample t-test for age differences are shown in Table 2. As seen in the table, the older group (21 and over) scored significantly higher on goal selection, planning, self-appraisal, and occupational information subscales than younger group (20 and below).

Table 2. Age Comparisons for the CDSE-SF

\begin{tabular}{|c|c|c|c|c|c|c|c|}
\hline \multirow[b]{2}{*}{ CDSE-SF Scale } & \multicolumn{2}{|c|}{$\begin{array}{l}20 \text { and Below } \\
(n=106)\end{array}$} & \multicolumn{2}{|c|}{$\begin{array}{c}21 \text { and Over } \\
(n=250)\end{array}$} & \multirow[b]{2}{*}{$t$} & \multirow[b]{2}{*}{$d f$} & \multirow[b]{2}{*}{$p$} \\
\hline & $M$ & $S D$ & $M$ & $S D$ & & & \\
\hline Self-Appraisal & 3.98 & 0.58 & 3.89 & 0.57 & 1.77 & 319 & .078 \\
\hline Occupational Information & 3.89 & 0.57 & 4.09 & 0.61 & 2.35 & 319 & $.019 *$ \\
\hline Goal Selection & 3.93 & 0.62 & 4.20 & 0.54 & 2.94 & 319 & $.004 * *$ \\
\hline Planning & 3.81 & 0.62 & 4.05 & 0.63 & 2.64 & 319 & $.009 * *$ \\
\hline Problem Solving & 3.53 & 0.68 & 3.55 & 0.70 & 0.18 & 319 & .852 \\
\hline TOTAL & 3.83 & 0.47 & 4.01 & 0.47 & 2.50 & 319 & $.013^{*}$ \\
\hline
\end{tabular}

\section{Major Differences}

Results of independent sample t-test for major differences are shown in Table 3. As seen in the table, students from engineering departments (Mechanical, Chemical, Geological, Environmental, Electrical \& Electronic, Geodesy \& Photogrammetry) scored significantly 
higher on goal selection, self-appraisal, and occupational information subscales than the students from social departments (Economy, Management, International Relations).

Table 3. Major Comparisons for the CDSE-SF

\begin{tabular}{|c|c|c|c|c|c|c|c|}
\hline \multirow[b]{2}{*}{ CDSE-SF Scale } & \multicolumn{2}{|c|}{$\begin{array}{c}\text { Social Depart- } \\
\text { ments } \\
(n=169)\end{array}$} & \multicolumn{2}{|c|}{$\begin{array}{c}\text { Engineering } \\
\text { Departments } \\
(n=187)\end{array}$} & \multirow[b]{2}{*}{$t$} & \multirow[b]{2}{*}{$d f$} & \multirow[b]{2}{*}{$p$} \\
\hline & $M$ & SD & $M$ & $S D$ & & & \\
\hline Self-Appraisal & 3.94 & 0.55 & 4.07 & 0.57 & 2.09 & 319 & $.037^{*}$ \\
\hline Occupational Information & 3.90 & 0.55 & 3.94 & 0.64 & 0.55 & 319 & .585 \\
\hline Goal Selection & 3.89 & 0.60 & 4.05 & 0.62 & 2.24 & 319 & $.026 *$ \\
\hline Planning & 3.78 & 0.65 & 3.91 & 0.60 & 1.92 & 319 & .055 \\
\hline Problem Solving & 3.56 & 0.68 & 3.52 & 0.68 & 0.51 & 319 & 609 \\
\hline TOTAL & 3.81 & 0.47 & 3.90 & 0.48 & 1.56 & 319 & .119 \\
\hline
\end{tabular}

\section{Discussion}

This study investigated the career decision-making self-efficacy in a sample of 356 Turkish undergraduate students. Similar to the results of Taylor and Betz (1983), majority of the students reported tasks about problem-solving as the most difficult, and self-appraisal and occupational information as the least difficult. As Taylor and Betz (1983) also stated, when designing interventions to increase the career decision self-efficacy of undergraduate students, this hierarchy could be useful beginning with relatively easy tasks and progressing with more difficult tasks as self-efficacy expectations are increased and strengthened and the focus of the interventions could be decided regarding this hierarchy. For instance, if the most difficult tasks are on problem-solving, then the practitioner could concentrate on activities involving problem-solving tasks. Likewise, if the least difficult tasks are on occupational information, then the practitioner could pay less attention on activities involving occupational information.

In terms of gender comparisons, no significant differences were found. This finding is consistent with previous research using college samples (e.g., Betz et al., 1996; Betz \& Voyten, 1997; Luzzo, 1993; Taylor \& Betz, 1983; Taylor \& Popma, 1990). Gender is not a significant factor influencing the career decision making self-efficacy. Regarding age differences, the older group scored significantly higher on goal selection, planning, self-appraisal, and occupational information subscales than younger group. This finding is also consistent with previous research (e.g., Betz et al., 1996; Betz \& Voyten, 1997; Creed, Patton \& Watson, 2002; Luzzo, 1993; Luzzo \& Ward, 1995; Taylor \& Betz, 1983). The older the students be- 
come, the more confident they are about their career decisions. This finding would also be considered as a support for the criterion validity of the Turkish version of CDSES-SF. It should further be examined whether CDSES-SF in other non-Enlish speaking countries shows similar characteristics in terms of gender difference.

Regarding major differences, students from engineering departments scored significantly higher on goal selection and self-appraisal subscales than the students from social departments. One possible explanation for this result would be that students studying in quantitative departments receive more support from their family since families perceive studying in quantitative fields as more difficult. There is a common belief among Turkish families that if a student can't do mathematics or physics, then he/she studies verbal fields. Therefore, verbal fields are seen peripheral when compared with quantitative fields. As Bandura (1997) postulated that social persuasion, that is, encouragement and support from others is one of the four learning experiences by which efficacy expectations are developed, encouragement and support engineering students received from their families and social environment would have developed their confidence in career decision making. Thus, when designing career interventions, social persuasion would be a significant learning source to increase the career decision self-efficacy of undergraduate students.

Overall, the results suggested that career-decision self-efficacy scores of Turkish undergraduate students were similar to the previous research conducted mostly in Englishspeaking countries. These findings would be a support for the use of CDSES-SF with Turkish undergraduates and its use in other non-English-speaking countries. Future research is encouraged to further explore such task difficulty, gender, age, and major differences using CDSES-SF with various populations in other non-English-speaking countries. 


\section{References}

Bandura, A. (1977). Self-efficacy: Toward a unifying theory of behavioral change. Psychological Review, 84, 191-215.

Bandura, A. (1986). Social foundations of thought and action: A social cognitive theory. Englewood Cliffs, NJ: Prentice Hall.

Bandura, A. (1995). Exercise of personal and collective efficacy in changing societies. In A. Bandura (Ed.), Self-efficacy in changing societies (pp. 1-45). New York: Cambridge University Press.

Bandura, A. (1997). Self-efficacy: The exercise of control. New York: Freeman.

Bethencourt, J. T. \& Cabrera, L. (2008). University students behaviours and professional career development. Electronic Journal of Research in Educational Psychology, 16, 6(3), 623-640.

Betz, N. E., \& Hackett, G. (1981). The relationship of career-related self-efficacy expectations to perceived career options in college women and men. Journal of Counseling Psychology, 28, 399-410.

Betz, N., \& Hackett, G. (1983). The relationship of mathematics self-efficacy expectations to the selection of science-based college majors. Journal of Vocational Behavior, 23, 329-345.

Betz, N. E., Hammond, M. S., \& Multon, K. D. (2005). Reliability and validity of five-level response continua for the Career Decision Self-Efficacy Scale. Journal of Career Assessment, 13, 131-149.

Betz, N. E., Klein, K. L., \& Taylor, K. M. (1996). Evaluation of a short-form of career decision making self-efficacy scale. Journal of Career Assessment, 4(1), 47-57.

Betz, N., \& Voyten, K. K. (1997). Efficacy and outcome expectation influence career exploration. Career Development Quarterly, 46, 197-189.

Blustein, D. L. (1989). The role of goal instability and career self-efficacy in the career exploration process. Journal of Vocational Behavior, 35, 194-203.

Cassidy, S \& Eachus, P. (2002). Developing the computer user self-efficacy (CUSE) scale: Investigating the relationship between computer self-efficacy, gender and experience with computers. Journal of Educational Computing Research, 26(2), 169-189.

Chung, Y. B. (2002). Career decision-making self-efficacy and career commitment: Gender and ethnic differences among college students. Journal of Career Development, 28, 277-284. 
Creed, P. A., Patton, W., \& Watson, M. B. (2002). Cross-cultural equivalence of the Career Decision-Making Self-Efficacy Scale-Short Form: An Australian and South African comparison. Journal of Career Assessment, 10, 327-342.

Crites, J. O. (1976). A comprehensive model of career development in early adulthood. Journal of Vocational Behavior, 9, 105-118.

Eastin, M. A., \& LaRose, R. L. (2000). Internet self-efficacy and the psychology of the digital divide. Journal of Computer Mediated Communication, 6(1). Retrieved November29, 2000 from the World Wide Web: http://www.ascusc.org/jcmc/vol6/issue1/eastin.html

Gushue, G. V., Clarke, C. P., Pantzer, K. M. \& Scanlan, K. R. L. (2006). Selfefficacy, perceptions of barriers, vocational identity and the career exploration behavior of Latino/a high school students. Journal of Career Development, 34, 307-317.

Hampton, N. Z. (2005). Testing for the structure of Career Decision Self-Efficacy Scale Short Form Among Chinese college students. Journal of Career Assessment, 13, 98113.

Lent, R. W. (2005). A social cognitive view of career development and counseling. In S. D. Brown \& R. W. Lent (Eds.), Career development and counseling: Putting theory and research to work (pp. 101-127). Hoboken, NJ: Wiley.

Lent, R. W., Brown, S. D., \& Hackett, G. (1994). Toward a unifying social cognitive theory of career and academic interest, choice, and performance. Journal of Vocational Behavior, 45, 79-122.

Lent, R. W., Brown, S. D., \& Hackett, G. (2002). Social cognitive career theory. In D. Brown \& Associates (Eds.), Career choice and development. 4th edition (pp. 255-311). San Francisco: Jossey-Bass.

Lopez, F.G., Lent, R.W., Brown, S.D., \& Gore, P.A. (1997). Role of social-cognitive expectations in high school students' mathematics-related interest and performance. Journal of Counseling Psychology, 44, 44-52.

Luzzo, D. A. (1993). Reliability and validity testing of the Career Decision-Making SelfEfficacy Scale. Measurement and Evaluation in Counseling and Development, 26, 137-142.

Luzzo, D. A., \& Ward, B. E. (1995). The relative contributions of self-efficacy and locus of control to the prediction of vocational congruence. Journal of Career Development, $21,307-317$. 
Martínez, J. M. (2007). Vocational and professional guidance through the Self Direct Research. Electronic Journal of Research in Educational Psychology, 11, 5(1), 233258.

Mau, W. (2000). Cultural differences in career decision-making styles and self-efficacy. Journal of Vocational Behavior, 57, 365-378.

Patel, S. G., Salahuddin, N. M. \& O'Brien, K. M. (2008). Career Decision-Making SelfEfficacy of Vietnamese Adolescents: The Role of Acculturation, Social Support, Socioeconomic Status, and Racism. Journal of Career Development, 34, 218-240.

Patton, W., \& Creed, P. A. (2001). Developmental issues in career maturity and career decision status. The Career Development Quarterly, 49, 336-351.

Rogers, M. E., Creed, P. A. \& Glendon, A. I. (2008). The role of personality in adolescent career planning and exploration: A social cognitive perspective. Journal of Vocational Behavior, 73, 132-142.

Taylor, K. M., \& Betz, N. E. (1983). Applications of self-efficacy theory to the understanding and treatment of career indecision. Journal of Vocational Behavior, 22(1), 63-81.

Taylor, K. M. \& Popma, J. (1990). An examination of the relationships among career decision-making self-efficacy, career salience locus of control, and vocational indecision. Journal of Vocational Behavior, 37, 17-31. 
[This page intentionally left blank] 